ИЗВЕСТИЯ АКАДЕМИИ НАУК ЭСТОНСКОН ССР. ТОМ 19 ХИМИЯ * ГЕОЛОГИя. 1970, № 4

\title{
НОВЫЕ ДАННЫЕ О ГЕОЛОГИИ РАЗРЕЗА КАРУКЮЛА
}

\section{(ЮГО-ЗАПАДНАЯ ЭСТОНИЯ)}

В периодизации позднего плейстоцена опорное значение имеет разрез Карукюла, расположенный в юго-западной части Эстонии, примерно в $7 \kappa м$ к югу от г. Килинги-Нымме, в дер. Карукюла-Кесккюла. Данный разрез имеет детальную геологическую (К. Орвику, К. Каяк), палинологическую (А. Лаази, Р. Пиррус, Э. Лийвранд), палеокарпологическую (Т. Колесникова), литологическую (К. Орвику, А. Раукас, К. Каяк) и радиохронометрическую (Я.-М. Пуннинг, Х. Арсланов) характеристики. Нєсмотря на наличие разностороннего, тщательно накопленного и хорошо систематизированного фактического материала, возраст отдельных слоев разреза Карукюла до последнего времени вызывает острую дискуссию. Полученные новые геологические и радиохронометрические данные позволяют авторам уточнить некоторые стороны формирования четвертичного покрова в этом ключевом для стратиграфии верхнего плейстоцена районе.

Разрез Карукюла приурочен к периферии Сакалаского плато, где на выположенном склоне пологого друмлина с абсолютными отметками около 60 м между двумя моренами на глубине $1-2 м$, примерно на площади в 1 га, залегает линза озерно-болотных осадков мощностью около 1,2 м. Эти осадки, детально изученные К. Орвику и др. (Orviku, 1944; Орвику, Пиррус, 1965 и др.), находятся в первичном залегании (Орвику, Пиррус, 1965).

Приведем некоторые данные геологической съемки* в окрестностях дер. Карукюла, по которым межморенные озерно-болотные отложения приурочены к верхам четвертичной толщи, заполняющей глубокую (около 200 м) эродированную в среднедевонские $\left(\mathrm{D}_{2}\right)$ и нижнесилурийские $\left(\mathrm{S}_{1}\right)$ породы древнюю долину северо-восточного и восточного простирания (рис. 1). В современном рельефе на слабодрумлинизированной и абрадированной озерно-ледниковой равнине долина не выражена. Буровыми скважинами она установлена несколько севернее пос. Икла близ дер. Треймани (дно ее расположено здесь на глубине около -120 м), дальше на северо-восток у дд. Пээду $(-110 \mu)$, Карукюла $(--142$ м) и пос. Абья $(-130 \mu)$, всего на протяжении около $60 \kappa м$.

В местонахождении озерно-болотных отложений Карукюла по разрезу буровой скважины (рис. 2, скв. 3) под озерными отложениями ниже 4,5 м залегает гравий флювиогляциального происхождения (мощностью 2,5 м), затем серая морена $(6,5$ м ) и опять флювиогляциальные песчаногравийные отложения $(24,2$ м); всего мощность четвертичных отложений

* Вяярси А. Р., Каяк К. Ф., Каяк Х. В. и др. Отчет о геолого-гидрогеологической съемке юго-западной части Эстонии, 1969. Фонды Упр. геол. СМ ЭССР. 
в этой скважине составляет $37,7 \mu$. В $0,6 \kappa \mu$ к северозападу от описанного разреза бурением были пройдены четвертичные отложения мощностью 207 м (скв. 2). Среди них бурая морена последнего оледенения $(3,4$ м ), глубже - серая морена $(73,3 м)$, переслаивание алеврита с гравием и песком $(19,4 м)$, коричневая морена (13,2 м), озерно-ледниковые алевриты $(59,7 \boldsymbol{M})$, коричневая морена $(15 \mathrm{M})$, озерноледниковые алевриты, глины $(20$ м) и снова коричневая морена $(3 \mu)$.

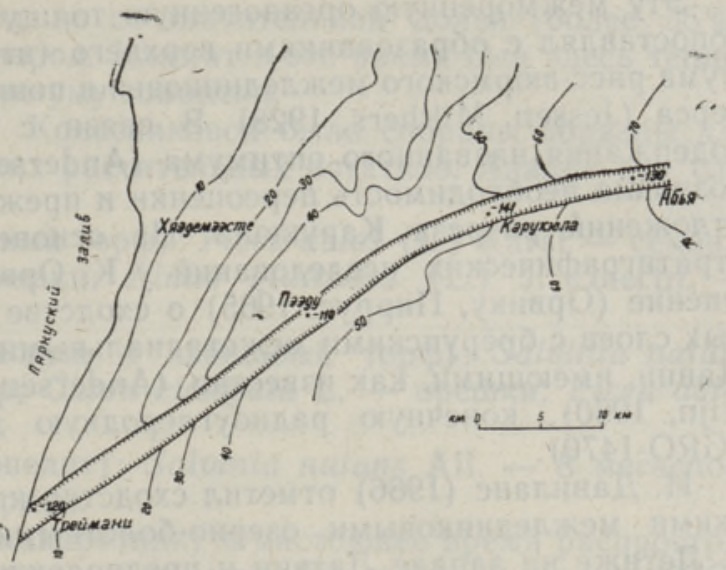

Рис. 1. Рельеф поверхности дочетвертичных пород: в Юго-Западной Әстонии.

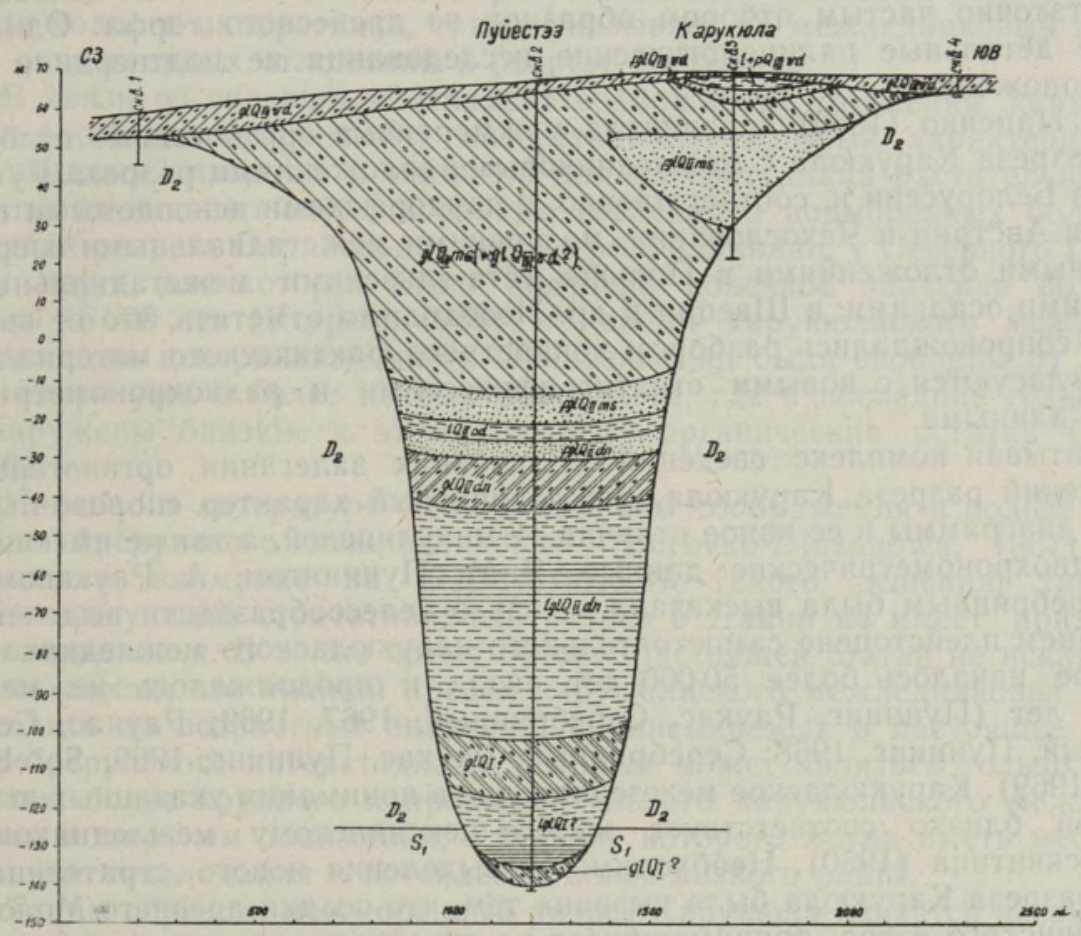

Рис. 2. Строение погребенной долины в районе дер. Карукюла:

Таким образом, в районе Карукюла развиты те же самые моренные. горизонты, которые весьма характерны для всей Южной Эстонии: под бурой мореной последнего оледенения залегают серая морена московского или нижневалдайского оледенения, затем коричневая морена, возможно днепровского оледенения и местами еще более древние морены (Каяк, 1965 и др.). Следовательно, озерно-болотные осадки Карукюла развиты между бурой мореной верхневалдайского и серой мореной нижневалдайского и московского оледенений. 
Эту межморенную органогенную толщу К. Орвику еще в 1941 году сопоставлял с образованиями верхнего (второго) климатического оптимума рисс-вюрмского межледниковья в понимании К. Нессена и В. Мильтерса (Jessen, Milthers, 1928). В связи с пересмотром геологического содержания названного оптимума (Andersen, 1957, 1961, Гричук, 1961), возникла необходимость переоценки и прежней датировки межморенных отложений разреза Карукюла. На основе новых палинологических и стратиграфических исследований у К. Орвику и Р. Пиррус сложилось мнение (Орвику, Пиррус, 1965) о сходстве карукюласких озерно-болотных слоев с брёрупскими межстадиальными отложениями на территории Дании, имеющими, как известно (Andersen, 1961, Andersen, Vries, Zagwijn, 1960), конечную радиоуглеродную датировку $59430 \pm 1000$ лет (GRO-1470).

И. Даниланс (1966) отметил сходство карукюласких слоев с лихвинскими межледниковыми озерно-болотными отложениями в бассейне р. Летиже на западе Латвии и предположил, что межморенные органогенные отложения в разрезе Карукюла могли тоже накопиться во время лихвинского межледниковья. Отсутствие в спорово-пыльцевом спектре разреза Карукюла пыльцы пихты, по его мнению, возможно связано с недостаточно частым отбором образцов из древесного торфа. Однако, новые детальные палинологические исследования не подтвердили его предположения.

М. Цапенко (1966) сравнивала межморенные органогенные отложения разреза Карукюла с межледниковыми отложениями разреза Рутковичи в Белоруссии и, соответственно, с паудорфскими ископаемыми почвами в Австрии и Чехословакии, мазурскими межстадиальными озерноболотными отложениями в Польше, гёта-эльвскими межстадиальными морскими осадками в Швеции и др. Необходимо отметить, что ее выводы не сопровождались разбором конкретного фактического материала и не согласуются с новыми стратиграфическими и радиохронометрическими данными.

Учитывая комплекс сведений об условиях залегания органогенных отложений разреза Карукюла, межледниковый характер спорово-пыльцевой диаграммы и ее явное отличие от микулинской, а также имеющиеся радиохронометрические данные, Я.-М. Пуннингом, А. Раукасом и Л. Серебрянным была высказана мысль о целесообразности выделения в позднем плейстоцене самостоятельного карукюлаского межледниковья которое началось более 50000 лет назад и продолжалось не менее 20000 лет (Пуннинг, Раукас, Серебрянный, 1967, 1969; Раукас, Серебрянный, Пуннинг, 1968; Серебрянный, Раукас, Пуннинг, 1969; Serebryanny, 1969). Карукюлаское межледниковье в понимании указанных выше авторов близко соответствует молого-шекснинскому межледниковью А. Москвитина (1950). Необходимость выделения нового стратотипа в виде разреза Карукюла была вызвана тем, что осадки древнего МологоШекснинского озера, принимавшиеся за стратотип, оказались микулинского возраста (Гричук, 1961).

Необходимо отметить, что некоторые исследователи (Малаховский и др., 1969; Вайтекунас, 1969 и др.), признавая верхнеплейстоценовый возраст разреза Карукюла, упорно защищают его межстадиальный ранг. Новые палинологические исследования, выполненные Ә. Лийвранд **, как и прежние, убедительно свидетельствуют в пользу межледникового ранга этих слоев. Во время климатического оптимума карукюлаского межледниковья на территории Юго-Западной Эстонии произрастали леса

* См. сноску на стр. 350 . 
с господством хвойных пород, но со значительной долей (более $35 \%$ ) пыльцы широколиственных пород. Климат в это время был здесь теплее современного и близок к оптимуму голоцена.

В 1965 г. К. Каяком и Т. Колесниковой были собраны образцы для определения макроскопических растительных остатков. Анализ дал следующий результат:

1. Глубина 1,6 м (древесный торф): Picea abies (L.) Karst - семена; Carex rostrata Stokes - oрешки; Alnus glutinosa (L.) J. Gaertn. орешек.

2. Глубина 1,9 м (древесный и хвощовый торф): Salvinia natans All. - очень много мегаспор; Carex elongata L. - орешки; Picea abies L. - семя.

3. Глубина 2,2 м (сапропелит): Salvinia natans All. - 8 мегаспор; Potamogeton sp. - 1 эндокардий.

Salvinia natans (водный папоротник) в настоящее время распространен гораздо южнее Карукюла - на юге Европейской части СССР (очень много в дельте Волги, по нижнему течению Дона, Днепра и др.). Все остальные приведенные выше виды растений в настоящее время широко развиты и в Әстонии. Присутствие перечисленных видов, в частнссти водного папоротника, также указывает на межледниковый характер органогенных отложений в разрезе Карукюла.

В связи со сказанным отпадает возможность отнесения карукюласких слоев и к брёрупскому интерстадиалу, который характеризуется прохладным климатом и типичной для интерстадиала растительностью. Учитывая недавно опубликованные сведения о подморенных болотных осадках разреза Перяпохьола на севере Финляндии, у Северного Полярного круга, для которых было получено конечное значение возраста около 45000 лет (Korpela, 1969), во время карукюлаского межледниковья даже центральные части Фенноскандии были свободны от льдов, не говоря уже о более южных районах ее, где в последние годы тоже обнаружены близкие к этому возрасту органические остатки (Sollid, 1969).

Недавно в литературе были высказаны соображения в пользу выделения брёрупского межледниковья (Borovko-Dlužakowa, 1967). Мы обращаем внимание на недопустимость такого решения, так как соответствующий стратотипичный разрез в Дании не имеет признаков межледниковья. В то же время авторы настоящей статьи не исключают возможности, что нижний предел карукюлаского межледниковья может доходить до возрастных значений, приписываемых в настоящее время для брёрупского интерстадиала, который может являться только одной частью более крупного и продолжительного карукюлаского межледниковья в широком понимании, в течение которого могли иметь место отдельные похолодания и потепления более низкого ранга.

Таким образом, межморенный разрез Карукюла является несомненно межледниковым и спор может происходить только на той почве, к какому возрастному интервалу отнести отдельные слои данного разреза. Учитывая приведенные выше данные об условиях залегания органогенного материала, результаты литологического изучения морен, позволяющих сделать определенные сопоставления, а также свежий облик органогенного материала, складывается представление о верхнеплейстоценовом возрасте этих органогенных осадков. Веским доказательством верхнеплейстоценового возраста карукюласких органогенных слоев служит гакже большое количество радиоуглеродных датировок, выполненных в ссновном Я.-М. Пуннингом в лаборатории геобиохимии Института зоологии и ботаники АН ЭССР.

6 ENSV TA Toimetised $\mathrm{K} * \mathrm{G}-41970$ 
Первый образец для радиоуглеродного датирования из разреза Карукюла был отобран Р. Пиррус в 1963 г. и направлен в ГЕОХИ, где был получен результат $\geqslant 33000$ лет (Мо-375) (Виноградов и др., 1966).

В 1965 году К. Каяком были отобраны образцы для радиоуглеродного анализа, результаты которого приведены в табл. 1 (Пуннинг и др., 1966a).

Таблица 1

\begin{tabular}{l|c|c|c|c}
\hline $\begin{array}{c}\text { Индекс и № } \\
\text { образца }\end{array}$ & $\begin{array}{c}\text { Пыльцевая } \\
\text { зона }\end{array}$ & $\begin{array}{c}\text { Глубнна залегания, } \\
\text { см (см. рис. 3, I) }\end{array}$ & Материал & $\begin{array}{c}\text { Возраст } \\
\text { от } 1950 \text { г. }\end{array}$ \\
\hline TA-99 & $\mathrm{K}_{4}$ & $150-170$ & Древесина & $33450 \pm 800$ \\
TA-100 & $\mathrm{K}_{4}$ & $150-170$ & Торф & $48100 \pm 1700$ \\
TA-101 & $\mathrm{K}_{3}$ & $195-215$ & Торф & $48100 \pm 1650$ \\
TA-106 & $\mathrm{K}_{2}$ & $235-255$ & Сапропелит & $\geqslant 45000$
\end{tabular}

Конечный возраст сапропелита получить не удалось, так как содержание органического вещества в образце оказалось недостаточным. Значение возраста древесины (ТА-99), возможно, занижено из-за загрязнения ее более молодым углеродом (Пуннинг и др., 1966а).

Недавно в радиоуглеродной лаборатории ЛГУ Х. Арслановым по образцу сильно разложившейся древесины из верхней части разреза Карукюла, представленному И. Красновым, была получена датировка $\geqslant 52780$ лет (ЛУ-44) (Малаховский и др., 1969 г.), что, однако, требует подтверждения на серийном материале.

В 1969 г. в местонахождении Карукюла были заново отобраны образцы для радиоуглеродного анализа.*** Шурф был заложен примерно в 20 м к юго-западу от того места, откуда в 1965 году были отобраны образцы К. Каяком. Образцы были отобраны с большой тщательностью и соблюдением всех правил отбора. Описание разреза весьма типично для местонахождения органогенных отложений Карукюла (рис. 3, II):

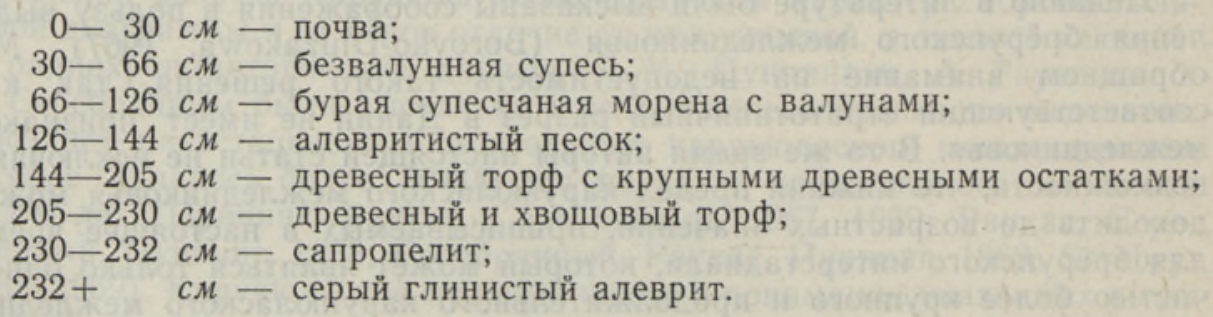

Радиоуглеродному анализу подвергались следующие образцы: 1) крупный, хорошо сохранившийся ствол древесины с глубины $165 \mathrm{~cm}$ от дневной поверхности; 2) древесный торф с древесными остатками с глубины 205 cм (контакт древесного и хвощового торфа); 3) хвощовый торф с глубины 230 см (самый нижний слой торфяного комплекса). Из торфа были взяты тонкослойные $(2-3 \mathrm{~cm})$ образцы.

Образцы торфа визуально видимых инородных органических примесей не содержали. Для удаления карбонатных и гумусовых компонентов была применена кислотно-щелочно-пирофосфатно-кислотная обработка (Пуннинг и др. 1966а). После обугливания очищенных от примесей образцов из них был синтезнрован бензол (Пуннинг и др., 1966б).

*** В полевых работах участвовали Я.-М. Пуннинг, Э. Лийвранд, Р. Пиррус, Т. Ринне и Л. Серебрянный. 
Измерения активности $\mathrm{C}^{14}$ в бензоле проводились с объемами $60 \mathrm{\mu}$, что обеспечивает датирование образцов с возрастами до 55 тыс. лег $\left(4 \sigma, 48\right.$ часов счета). Измерения счета $\mathrm{C}^{14}$ в образце были предприняты 4 раза по 24 часа, причем после каждого измерения контролю в течение 24 часов подвергался и фон. Скорость счета современного препарата измеряли 2 раза по 24 часа. При вычислении результатов использовалось значение полураспада $\mathrm{C}^{14}$, равное $5568 \pm 30$ лет. Полученные результаты (табл. 2) еще раз определенно свидетельствуют о верхнеплейстоценовом возрасте рассматриваемых межморенных отложений.

Таблица 2

\begin{tabular}{c|c|c|c}
\hline $\begin{array}{c}\text { Индекс и № } \\
\text { образща }\end{array}$ & $\begin{array}{c}\text { Глубина залегания, } \\
\text { см (см. рис. 3, ІІ) }\end{array}$ & \multicolumn{1}{c}{ Материал } & $\begin{array}{c}\text { Возраст } \\
\text { (от 1950 г.) }\end{array}$ \\
\hline ТА-275 & 165 & Древесина & $40800 \pm 700$ \\
TA-276 & 205 & Древесный торф с об- & $47800 \pm 1100$ \\
TA-277 & 230 & Хомками древесины & $48800 \pm 1200$ \\
\hline
\end{tabular}

В заключение нам хотелось бы коротко остановиться еще на одной, широко дискутируемой в настоящее время проблеме. Как известно, в последние годы многие исследователи северных районов страны подвергали острой критике традиционные представления о материковых оледенениях, либо полностью отрицая возможность существования обширных континентальных ледниковых покровов, либо признавая такую возможность лишь в ограниченных масштабах. Вместо обширных ледниковых покровов допускается широксе распространение крупных холодных морских бассейнов, а разнос обломочного материала связывают с деятельностью разных типов морских льдов (айсбергов, паковых льдов, шельфовых ледников и пр.). Наиболее веским аргументом для заключения о субаквальном генезисе валунных суглинков обычно считается наличие морской фауны в этих отложениях. Авторами совместно с кафедрой криолитологии и гляциологии МГУ были предприняты комплексные исследования генезиса валунных суглинков в некоторых районах Эстонии. Не вдаваясь в детальное обсуждение этого вопроса на более широком материале, отметим лишь то, что отложения из скв. Карукюла (Пуйестээ) подвергались детальному (всего просмотрено 43 образца) микропалеонтологическому

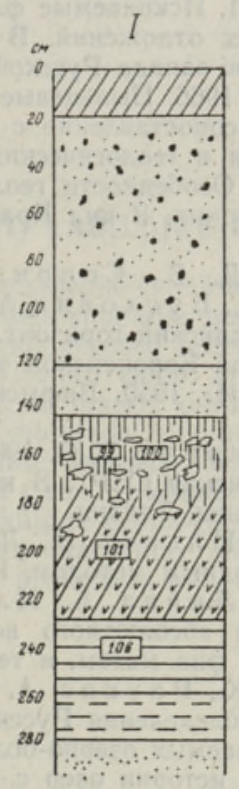

II

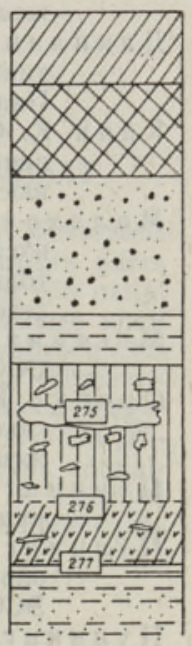

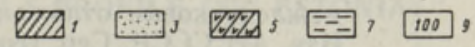

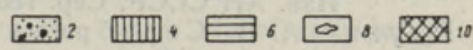

Рис. 3. Строение разреза озерноболотных отложений в Карукюла с указанием места отбора образцов для радиоуглеродного определения в 1965 (разрез I) н 1969 (разрез II) годах: $I$ - гумусовый слой (почва); 2 - бурая морена: 3 - песок; 4 - древесный торф: 5 - хвощовый торф; 6 - сапропелит; 7 алевритистый песок и глинистый алеврит: 8 - остатки древесины; 9 - место отбора образцов для радноуглеродного определения с номером образца; 10 - безвалунная супесь. 
нсследованию, но ни диатомовые водоросли, ни фораминиферы, ни остракоды, ни спикулы губок по всему профилю здесь не были обнаружены (заключение старшего инженера Ин-та океанологии АН СССР Г. Голиковой и инженера кафедры криолитологии и гляциологии МГУ Г. Недешевой). Полученные результаты согласуются с другими геологическими данными и говорят о супрааквальном генезисе валунных суглинков разреза Карукюла.

Таким образом, полученные новые геологические данные по разрезу Карукюла говорят о правомерности выделения второго позднеплейстоценового (карукюлаского) межледниковья и свидетельствуют о том, что оледенения в районе Карукюла протекали в типичных континентальных условиях.

\section{ЛИ ТЕ РА Т У Р А}

В а й те к ун а с П. П. 1969. О стратиграфическом подразделении неоплейстоцена гляциальной области (на примере Прибалтики). В кн.: Материковое оледенение и ледниковый морфогенез, Вильнюс.

Виноградов А. П., Девирц А. Л., Добкина Э. И., Марков а Н. Г. 1966. Данные радиоуглеродной лаборатории Института геохимии и аналитической химии им. В. И. Вернадского АН СССР. В сб.: Верхний плейстоцен, стратиграфия и абсолютная геохронология, $\mathrm{M}$.

Г ри чук В. П. 1961. Ископаемые флоры как палеонтологическая основа стратиграфни четвертичных отложений. В кн.: Рельеф и стратиграфия четвертичных отложений северо-запада Русской равнины, $M$.

Д а н и л а с И. Я. 1966. Пыльцевые зоны миндель-рисских отложений бассейна р. Летиже и их сопоставление с аналогичными зонами в других районах. В сб.: Палинология в геологических исследованиях Прибалтики, Рига.

К а я К. Ф. 1965. Особенности геологического строения краевых ледниковых образований в Эстонии. В кн.: Краевые образования материкового оледенения, Вильнюс.

Малаховский Д. Б., Спиридонова Е. А., Котлукова И. В., Бака н о в а И. П., Б у сло в и ц А. Л., К в а со в Д. Д. 1969. Строение четвертичной толщи. Валдайский горизонт. В кн.: Геоморфология и четвертичные отложения северо-запада Европейской части СССР, Л.

Москвитин А. И. 1950. Вюрмская эпоха (неоплейстоцен) в Европейской части CCCP, M.

О р в ик у К. К.. Пи р р у с Р. О. 1965. Межморенные органогенные отложения в Карукюла (Эстонская ССР). В кн.: Литология и стратиграфия четвертичных отложений Эстонии, Таллин.

П уннин г Я.-М., И льв е с Э., Лийв а А. 1966а. Датирование древних образцов радисуглеродным методом. Изв. АН ЭССР, Сер. биол., 15, № 4.

П унн инг Я.-М., Л и й в А А., И льв е С Э. 1966б. Усовершенствованная методика определения абсолютного возраста по природному радноуглероду. Изв. АН ЭССР, Сер. физ.-матем. и техн. н., 15, № 2.

Пунннинг Я.-М. К., Р аука с А. В., Серебрянны й Л. Р. 1967. Геохронология последнего оледенения Русской равнины в свете новых радноуглеродных датировок ископаемых озерно-болотных отложений Прибалтики. Материалы II симпозиума по истории озер с.-3. СССР (23-28 мая 1967.г.), Минск.

П уннин г Я.-М. К., Р а у к с А. В., С ер еб янны й Л. Р. 1969. Карукюлаские межледниковые отложения Русской равнины (стратиграфия и геохронология). Изв. АН СССР, Сер. геол., № 10, M.

Р аукас А. В., Серебрянны й Л. Р., Пуннинн Я Я.-М. К. 1968. Об абсолютном возрасте краевых зон и эволюции оледенения на северо-западе Русской равнины в позднем плейстоцене. Тезисы докл. Всес. межведомств. совещания по изучению краевых образований материкового оледенения, Смоленск.

С ер еб рянны й Л. Р., Р а ук а с А. В., Пуннин г Я.-М. К. 1969. К историн развития оледенения на северо-западе Русской равнины в верхнем плейстоцене. Материалы гляциолог. исслед., хроника, обсуждения, 15, М.

Ц а пенко М. М. 1966. Основные вопросы геологии и палеогеографии антропогена Белоруссии. Автореф. дисс. докт, геол.-мин, н., М.

Andersen S. T. 1957. New investigations of interglacial fresh-water deposits in Jutland. Eiszeitalter und Gegenwart, 8.

Andersen S. T. 1961. Vegetation and its environment in the Early Weichselian Glacial Last. Danmarks Geol. Unders., rk. 2, Nr. 75. 
Andersen S. T., de Vries H., Z a g wijn W. H. 1960. Climatic change and radiocarbon dating in the Weichselian Glacial of Denmark and the Netherlands. Geol. in mijubow, Jg. 39, Nr. 2.

B orowko-D l uža kova Z. 1967. Palaeobotanical studies of Late Pleistocene deposits Brorup) in the Konin - Marantow area (Summary). Czwartorzed wysoczyzny polnocnokoninskiej. Inst. geol. Prace, XLVIII, Warszawa.

Jessen K., Milthers V. 1928. Stratigraphical and palaeontological studies of interglacial fresh-water deposits in Jutland and North-West Germany. Danmarks Geol. Unders., rk. 2, Nr. 48, København.

Korpela K. 1S69. Die Weichsel-Eiszeit und ihr Interstadial in Peräpohjola (Nördliches Nordfinnland) im Licht von submoränen Sedimenten. Ann. Acad. Sci. Fennicae, Ser. A, III, Geologica-Geographica, 99, Helsinki.

O rviku K. 1944. Jääaegade geoloogiast Eestis. Eesti Sōna, 138.

Serebryanny L. R. 1969. L'apport de la radio-chronométrie a l'etude de l'histoire Tardi-Quaternaire des régions de glaciation ancienne de la Plaine Russe. Rev. géogr. phys, et géol. dynamique (2), XI, 3, Paris.

S o 11 i d J. L. 1969. A 48,000 years old tree stump presumably of spruce, found in Ringerike, South Norway. Norsk Geogr. Tidsskr., 23, 3.
Ннститут геологии
Академии наук Эстонской ССР
Поступила в редакцию
$11 /$ III 1970

Управление геологии

Совета Министров Эстонской ССР

K. KAJAK, J.-M. PUNNING, A. RAUKAS

\section{UUSI ANDMEID KARUKOLA (EDELA-EESTI) LÄBILOIKE GEOLOOGIAST}

Olulise stratigraafilise tähendusega Karuküla moreenidevahelise soo- ja järvesetete leiukoht paikneb sügava (ligikaudu $200 \mathrm{~m}$ ) kirde-edela-suunalise mattunud ürgoru piires (joon. 1). Tōenäoliselt primaarses asendis asuvad organogeensed setted lamavad siin neljal liustikuvee setetega eraldatud eriilmelisel moreenihorisondil (joon. 2). Kuni viimase ajani diskuteeritava vanusega Karuküla soo- ja järvesetted on ilmselt kuhjunud jäävaheaegsetes tingimustes, millele viitab rohke laialehiste puude tolmuterade leidumine setetes (klimaatilise optimumi ajal rohkem kui $35 \%$ ) ning nende liigiline koosseis. Salvinia natansi megaspooride esinemine jne. Absoluutse vanuse määrangud (joon. 3) kinnitavad, et Karuküla jäävaheaegsed setted kuhjusid hilispleistotseenis. Mitmeküligne geoloogiline andmestik vôimaidab autoritel toetada arvamust teise hilispleistotseeni (karuküla) jäävaheaja olemasolust Vene tasandikul ning väita, et jäätumised Karuküla piirkonnas olid tüüpilised mandrijäätumised.

\section{K. KAJAK, J.-M. PUNNING, A. RAUKAS}

\section{NEW DATA ON THE GEOLOGY OF THE KARUKULLA PROFILE (SW ESTONIA)}

The intermoraine bog and lacustrial deposits of Karuküla, which are of considerable stratigraphic significance, lie within the boundaries of a deep (ab. $200 \mathrm{~m})$ buried ancient valley of a NE-SW orientation (Fig. 1). The organogenic deposits of a primary position lie here at four different moraine horizons which are separated from each other by fluvioglacial and limnoglacial deposits (Fig. 2). The bog and lacustrial deposits of Karuküla, whose age has been under discussion up to the recent times, were obviously accumulated under interglacial conditions, evidence of which is the high content of the pollen of broad-leaved trees (over 35 per cent in the climatic optimum time) and the composition of the tree species as well as the occurrence of the megaspores of Salvinia natans, etc. The determinations of the absolute age (Fig. 3) confirm the fact that the interglacial deposits of Karuküla were formed in the Late Pleistocene. Manysided geological data allow the authors to support the assumption concerning the existence of a second Late Pleistocene (Karuküla) interglacial time on the Russian plain and assert that the glaciations in the area of Karuküla were typical continental glaciations. 